\title{
HUMAN CAPITAL TRAJECTORY: PERFORMANCE OF ALBANIA AND SERBIA IN CATCHING UP THE EU COUNTRIES
}

\author{
Eglantina Hysa \\ Eglantina Hysa \\ Epoka University, Faculty of Economic and Administrative Sciences \\ ehysa@epoka.edu.al \\ Article info \\ Paper category: Preliminary paper \\ Received: 23.1.2018. \\ Accepted: 8.6.2018. \\ JEL classification: $\mathrm{C}_{1} 3, \mathrm{I}_{25}, \mathrm{O}_{4} \mathrm{O}$
}

Keywords Human Capital; Economic Growth; Gender Disparity 


\section{ABSTRACT}

Purpose. This paper focuses on the measurement of the human capital level in Albania, Serbia and European Countries and in identifying the gaps between them. In addition, it focuses on the link between human capital and the Gross Domestic Product (GDP), by extending the analyse in finding the gender disparity of human capital and GDP relationship. Lastly, this study estimates the growth rate of the human capital level for Albania and Serbia and make a comparison with the average human capital of the European Countries.

Methodology. The methodology used in the calculation of the growth rate of human capital is exponential trend method which makes possible the estimation of the years needed for Albania and Serbia to catch up the average of EU-28. The data employed mostly in the above-mentioned analysis is the data set taken from Barro and Lee (2010) corresponding the Educational Attainment Data from 1950 to 2010. For the estimation of the growth rate of the human capital level, additional data until 2015 have been used compiled from the UIS database and UN population database, respectively.

Findings. The findings show that Albania has a higher probability of an earlier convergence than the Serbia has. Even though the proxy of human capital for year 2010 for Albania (9.85), is lower than Serbia (10.97), Albania is experiencing a rapid increase in the average years of schooling.

Limitations. But again, the study is limited to data related to only the years of schooling without considering the quality of education and skills acquired.

Originality. This study can serve as a contributor to the performance examination of Albania and Serbia to the EU community with regard to human capital accumulation. 


\section{INTRODUCTION}

The current and potential candidate countries to join EU - Albania, Bosnia and Herzegovina, the former Yugoslav Republic of Macedonia, Kosovo, Montenegro and Serbia - are facing new challenges comparing to the previous EU candidates. One of the most important challenges remains the difficulty the Western Balkan (WB) countries are having in transition to democracy which is accompanied to economical distortions. WB countries are very often having reforms and structural changes creating loss in welfare, which means economical distortion. This transition could negatively affect various sectors, especially the education sector.

There are numerous studies examining the relationship between human capital and economic growth, as well as the strength and the direction of such relationship. Human capital accumulation serves as a pushing engine to economic growth. According to Lucas (1993), the main engine of growth is the accumulation of human capital - of knowledge-and the main source of differences in living standards among nations is differences in human capital. Empirical evidence strongly supports the theory too, adding that not only human capital positively affects the economic growth of a country, but the economic growth, in turn, positively influences the human capital.

Comparing the micro and macro studies, micro studies are found to be consistent with the finding that years of schooling, acquired skills, etc., tend to have higher probability to be employed and higher incomes. Whereas macro studies have suffered to be consistent and the findings have been controversy (Pritchett, 2001). Since literature review offers such controversies, the main aim of the paper is to explore the literature regarding the relationship among these two variables and the proxies used for human capital accumulation. Secondly, the study aims to compare the performance of WB countries with EU countries with regard to linkage of human capital with gender disparity and per capita GDP. Lastly, the study aims to estimate the years needed for Albania and Serbia in converging the EU level of capital accumulation.

This study focused on the two Western Balkan countries given the available of data starting from 1950. The time series dataset was essential for this study because growth rate calculations needed to be made. The paper is organized five section including introduction: Section 2 presents a literature review of the link between human capital accumulation and economic growth. Section 3 describes the human capital in Albania, Serbia and EU countries, including the gender disparity, and its relationship to per capita GDP. Section 4, estimates the number of years needed for Albania and Serbia to catch up the EU countries. Section 5 summarizes main findings and concluding remarks. 


\section{LITERATURE REVIEW}

Since the 1960s, examining the link between human capital and economic growth using micro and macro theoretical and empirical approaches has been a great interest of scholars. From the microeconomic perspective, the level of education has a direct impact on the individual's income. Education increases the probability to be employed, the individual's labor productivity, skills' enhancement and the chance to fit the market needs. From the macroeconomic perspective, human capital is seen as the promoter of the economy. Education improves labour productivity, pushes the technology and innovation, increases returns to capital by supporting a sustainable economic growth. Madsen and Murtin, in 2017, found that the contribution of education in Britain has been equally important before and after the first industrial revolution. The empirical studies strongly support the fact that both, quantitative and qualitative education have positive effects on economic growth. Some of the key studies are being mentioned as below.

Although the definition of human capital is clear, measuring it still remains ambiguous, because it is hard to measure both the quantitative and qualitative education and it is much more difficult while trying to compare countries by using these measurements.

Different empirical studies have used different proxies of education in order to measure the impact of education on economic growth.

The main proxies of the education quantity founded in the literature review have been:

- Schooling enrolment ratios (Barro, 1991; Mankiw et al., 1992; Levine and Renelt, 1992),

- The average years of education/schooling (Barro and Lee, 1996, 2001 and 2010; Cohen and Soto, 2007; Hanushek and Woessmann, 2007; Krueger and Lindahl, 2001),

- Adult literacy rate (Azariadis and Drazen, 1990; Romer, 1990; Durlauf and Johnson, 1995),

- Education spending (Baldacci et al., 2008).

Most of these studies found a strong relationship between education quantity and economic growth and the education's positive effect on economic growth (Krueger and Lindahl, 2001; Temple, 1999). Education facilitates the spread of innovation, technological progress, so the economic growth and because of wealthy economies, countries can invest more and more in education. However, this relationship can exist just from one side; either the education pushes economic growth or economic growth pushes education. In a very few studies the link between these two variables is found to be weak or even negative (Islam, 1995; Bils and Klenow, 2000; Pritchett, 2001). In some other studies education quantity and economic growth are found to be totally unrelated (Benhabib and Spiegel, 1994). The main proxies of the educa- 
tion quality in the literature review are founded to be: survival rates, repetition rates, student/teacher ratios, schooling life expectancy, trained teachers in primary education, and education test scores.

The empirical studies that have used the education quality to examine the relationship with the economic growth are found to be relatively rare compared to the usage of the education quantity in the identification of this relationship.

Barro (1990) has measured the schooling quality by using the data on student scores and he found a positive relationship between schooling quality and economic growth. Hanushek and Kim (1995), Hanushek and Kimko (2000), Hanushek and Woessmann (2007) in their study were focused on mathematical and sciences skills concluding that these skills have strong impact on economic growth.

\section{HUMAN CAPITAL STOCK IN ALBANIA, SERBIAAND EUROPEAN COUNTRIES}

Two different data sets were used to describe the stock of human capital in Albania, Serbia and European Countries. The first data set is the international comparable data from Barro and Lee (2010) covering all European Countries and just two countries from Western Balkans, Albania and Serbia for the time period 1950-2010. This data shows the average years of schooling among the population aged 25 years old and over. Meanwhile, the second data source is based on data set offered by Human Development Report of United Nations Development Program (2015). This data set covers some detailed records for the time period of 2005-2014 for all European Countries including Albania and Serbia. This data set also shows the average years of schooling among the population aged 25 years old and over.

Figure 1. presents average years of schooling for the EU member countries as well as Albania and Serbia. Moreover, EU-28 has been added to the list of these countries. EU-28 shows the average of all actual European Counties and it is used as a reference point for a comparison with Albania and Serbia. 
Figure 1.: Average Years of Schooling in EU Countries, Albania and Serbia, 2010

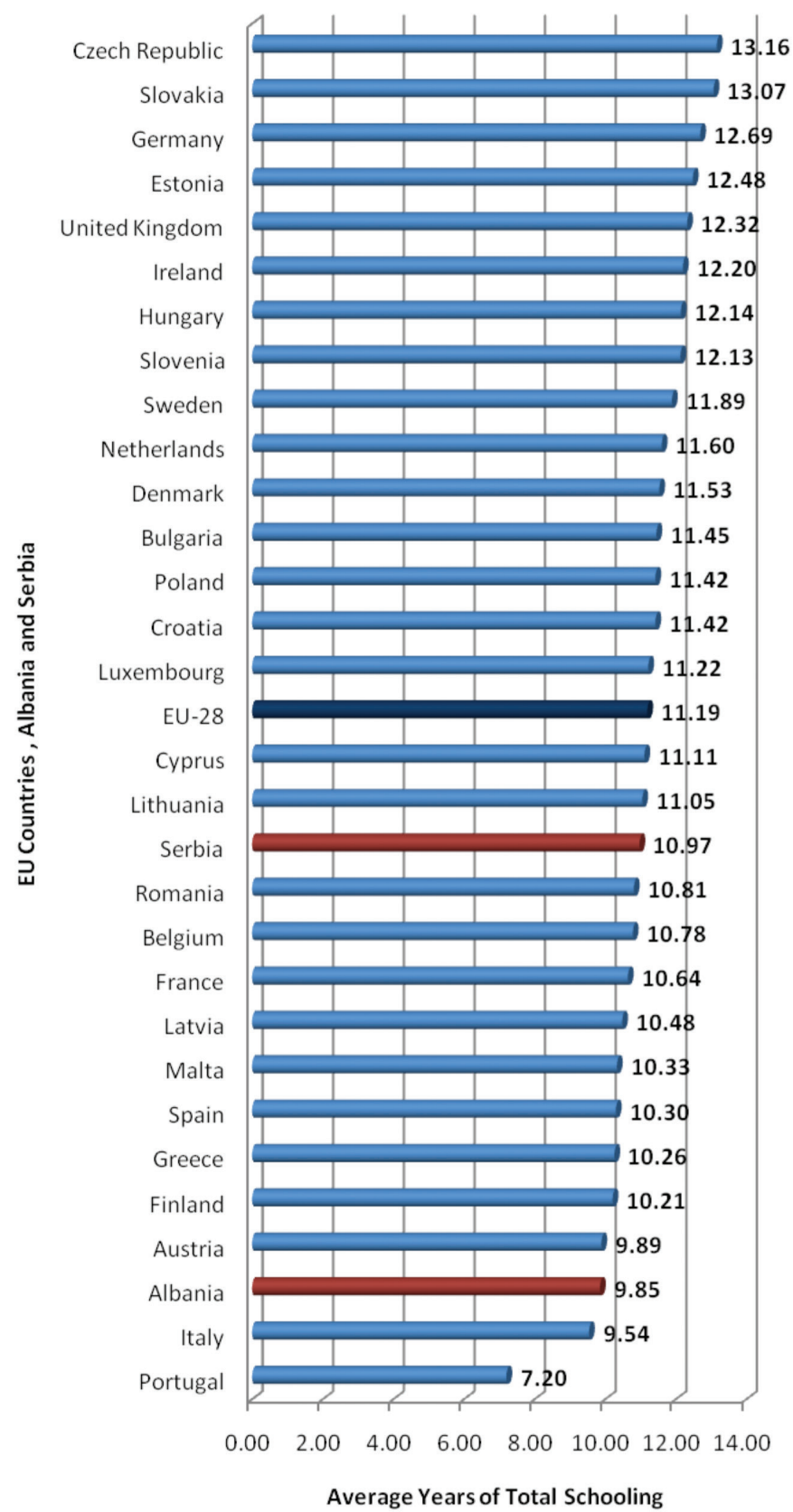

Source: Author's calculations based on Barro and Lee's (2010) data set. 
The countries have been listed in descending order in terms of average years of schooling. Barro and Lee's dataset offers the average years of total schooling, whereas the value for EU-28 has been calculated by taking the average of all EU countries. The top five countries representing the highest average years of schooling are Czech Republic, Slovakia, Germany, Estonia and United Kingdom. Czech Republic is placed in the top list, having an average years of schooling per total of population equal to 13.16 and respectively 13.3 for males and 13.03 for females. Portugal and Italy are at the bottom of the list. Even though both Albania and Serbia show low level of average years of schooling comparing to the EU-28, Serbia appears just two countries below the EU average.

Figure 2. presents average years of schooling and gender disparity in EU-28, Albania, and Serbia. The gender disparity is defined as the ratio of females' and males' average years of schooling. In all of these three cases, the average years of schooling has been higher for male comparing to the female population. Even though the average years of schooling in Albania is lower comparing to both Serbia and EU-28, Albania shows a better performance in the gender disparity. Specifically, gender disparity is 0.97 in EU-28, 0.94 in Albania, 0.91 in Serbia.

Figure 2.: Average Years of Schooling and Gender Disparity in EU-28, Albania and Serbia, 2010

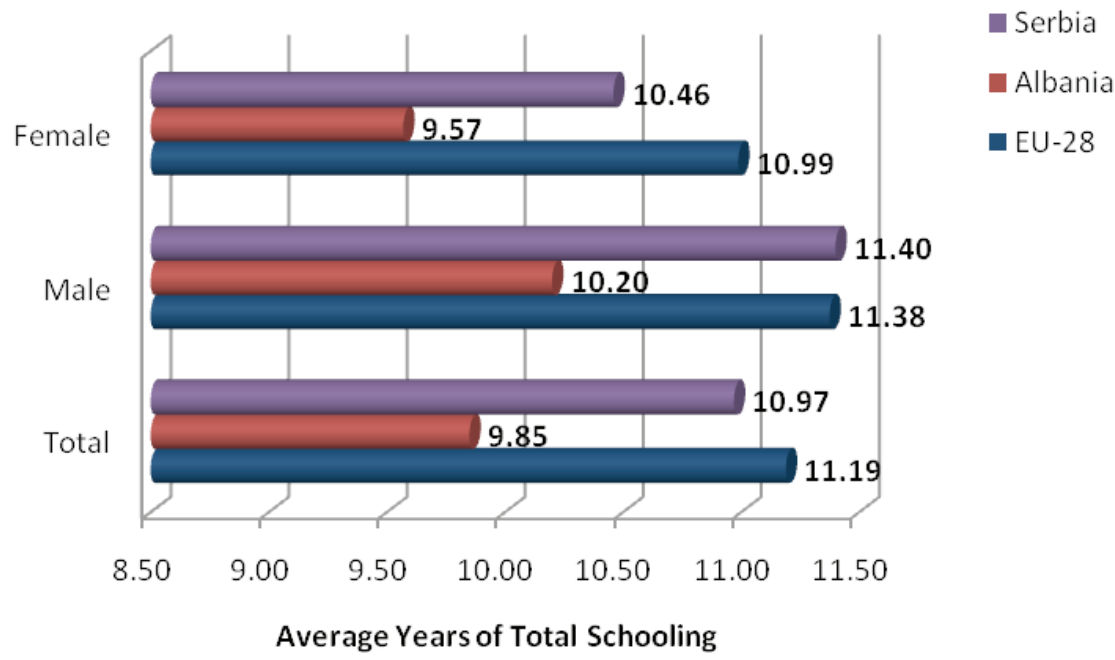

Source: Author's calculations based on Barro and Lee's (2010) data set.

Figure 3. presents gender disparity in each of the EU member countries (EU28) as well as in Albania and Serbia. The countries have been arranged in ascending order in terms of gender disparity. A total of six countries are found to have a gender disparity greater than 1 , which means that the female population has higher average years of schooling than male population. Estonia is the top country representing the 
widest gap of about 1.04, between females and males regarding gender disparity. Other countries having females' education higher than males' one are: Ireland, Sweden, Belgium, Finland and Latvia. Meanwhile, the rest of the countries have relatively high average years of schooling for males comparing to females. The highest gender disparity is found to be in Luxemburg, showing a ratio of about o.88. RegardingAlbania and Serbia, even though Serbia has a higher average years of schooling comparing to Albania, Albania fairs better in terms of gender disparity. The gender disparity is 0.94 in Albania and 0.91 in Serbia whereas this ratio is around 0.97 for the EU-28.

Figure 3.: Gender Gap in Average Years of Schooling, 2010

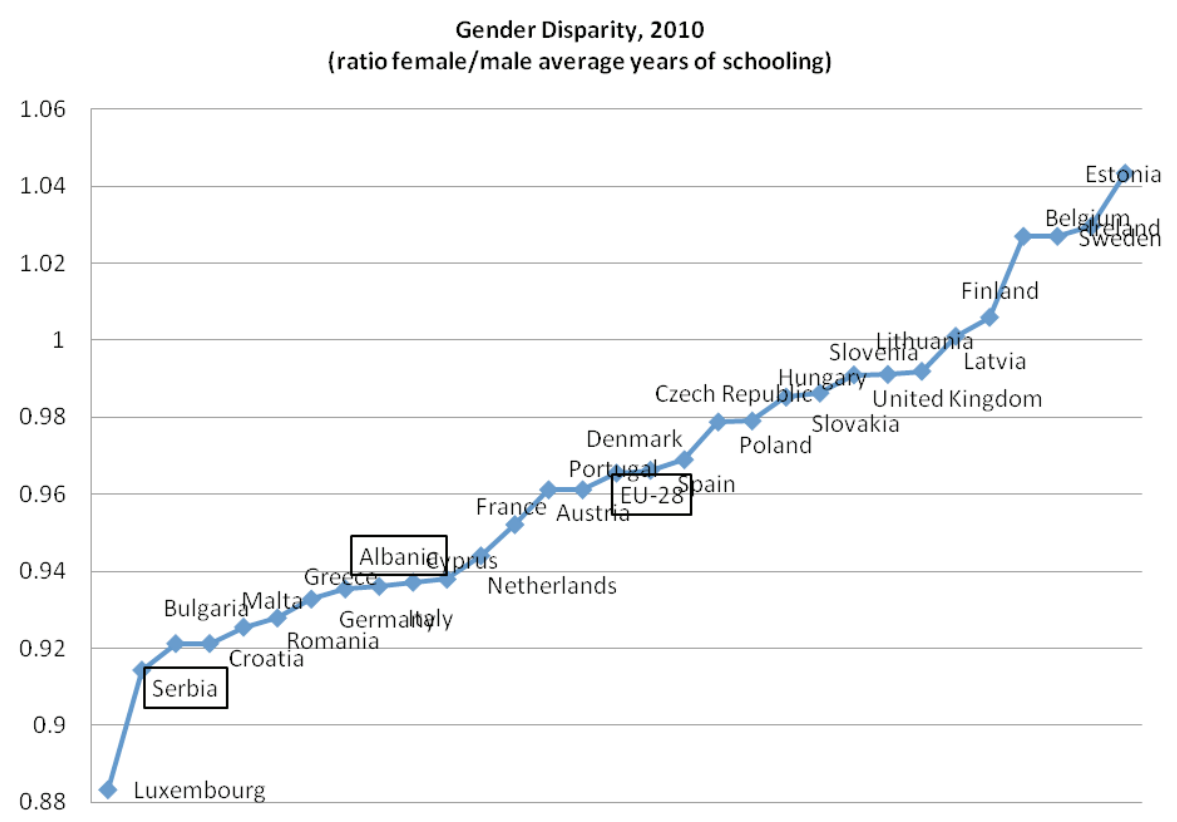

Source: Author's calculations based on Barro and Lee's (2010) data set.

The relationship between economic growth and human capital can be seen in Figure 4. The countries have been arranged in ascending order regarding their per capita gross domestic product (GDP). Figure 4. plots average years of schooling for each corresponding country. As expected and based on the previous works, gross domestic product should increase because of an increase of the education level. Contrary to the expectations, the trends of these two variables do not support this direct link. The reason of this result most probably is because the there are other important factors that influence the GDP. Dellink et al. (2017) also have come to some conclusion that countries such as Tanzania have more scope to boost economic growth by improving education levels than e.g. the United States (of course, in level terms, higher education levels still imply higher income levels, ceteris paribus). 
Even though Albania and Serbia are the countries having the lowest per capita GDP, Serbia has been thriving in catching up the performance of most of the EU countries with regard to the average years of schooling. Within the group of the EU countries, Portugal and Luxemburg are listed as the outliers. Portugal, having a middle per capita GDP in the group of EU countries, has an average years of schooling of about 7.20. This is the lowest level of average years of schooling in EU zone. Portugal rests even behind the two WB countries, respectively Albania and Serbia. Meanwhile, Luxemburg represents the other extreme case. It has the highest per capita GDP in the EU, but the performance of average years of schooling is not in line with that of per capita GDP.

Figure 4.: Average Years of Schooling by Distribution of per capita GDP, 2010

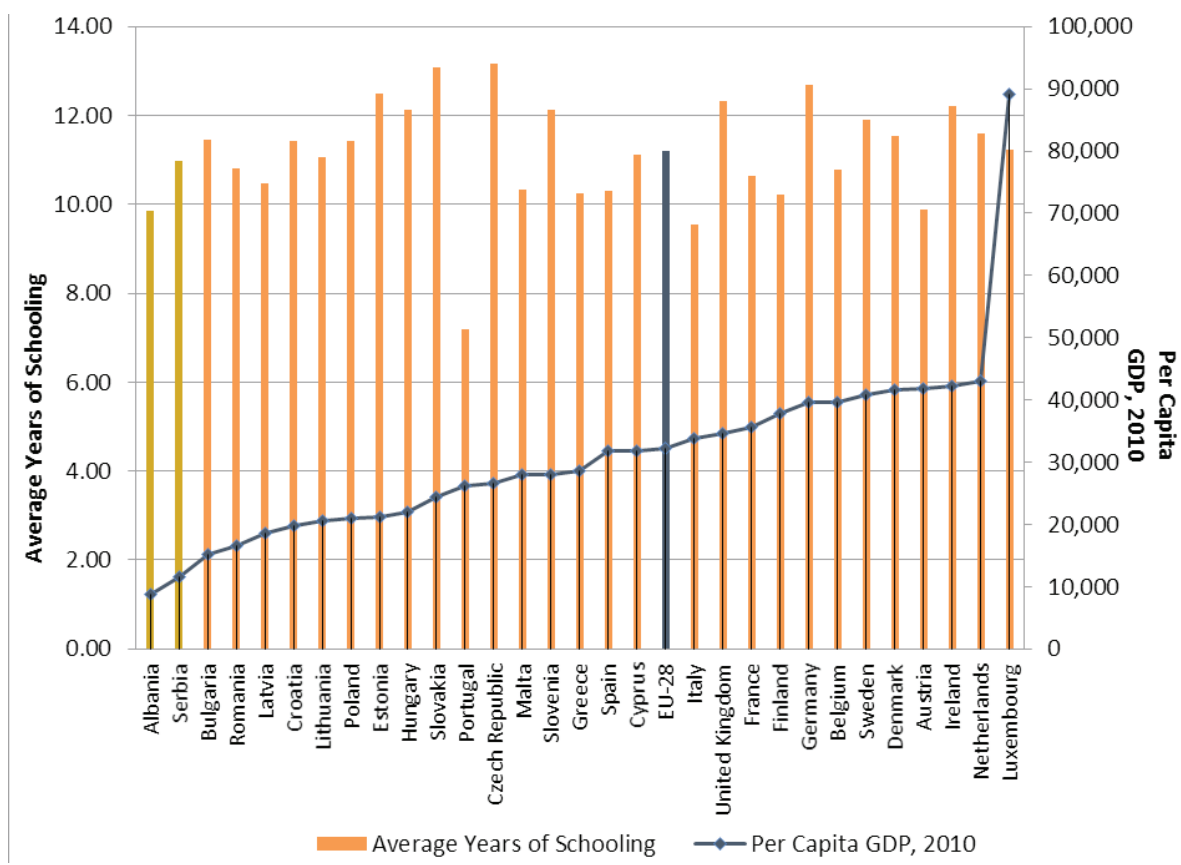

Source: Author's calculations based on Barro and Lee's (2010) data set.

Figure 5 . depicts the relationship of economic growth and gender disparity. As in the previous chart, the countries have been arranged in ascending order regarding their per capita gross domestic product. Additionally, gender disparity has been plotted for each corresponding country. In the EU group, Latvia is the only country representing a gender disparity equal to one, even though it is the third country listed at the end regarding low level of per capita GDP in the European Union.

Luxemburg, Croatia, Greece and Malta show large gender disparities; males having higher average years of schooling females: $0.88,0.92,0.93$ and 0.93 , respec- 
tively. Luxemburg, as seen at the previous figure, seems to have high per capita GDP but a significant gap between males' and females' education level. This finding appears to be contrary to the observation made by Klasen (2002), who indicated that gender disparity in education may slow down economic growth.

Figure 5.: Gender Disparity by Distribution of per capita GDP, 2010

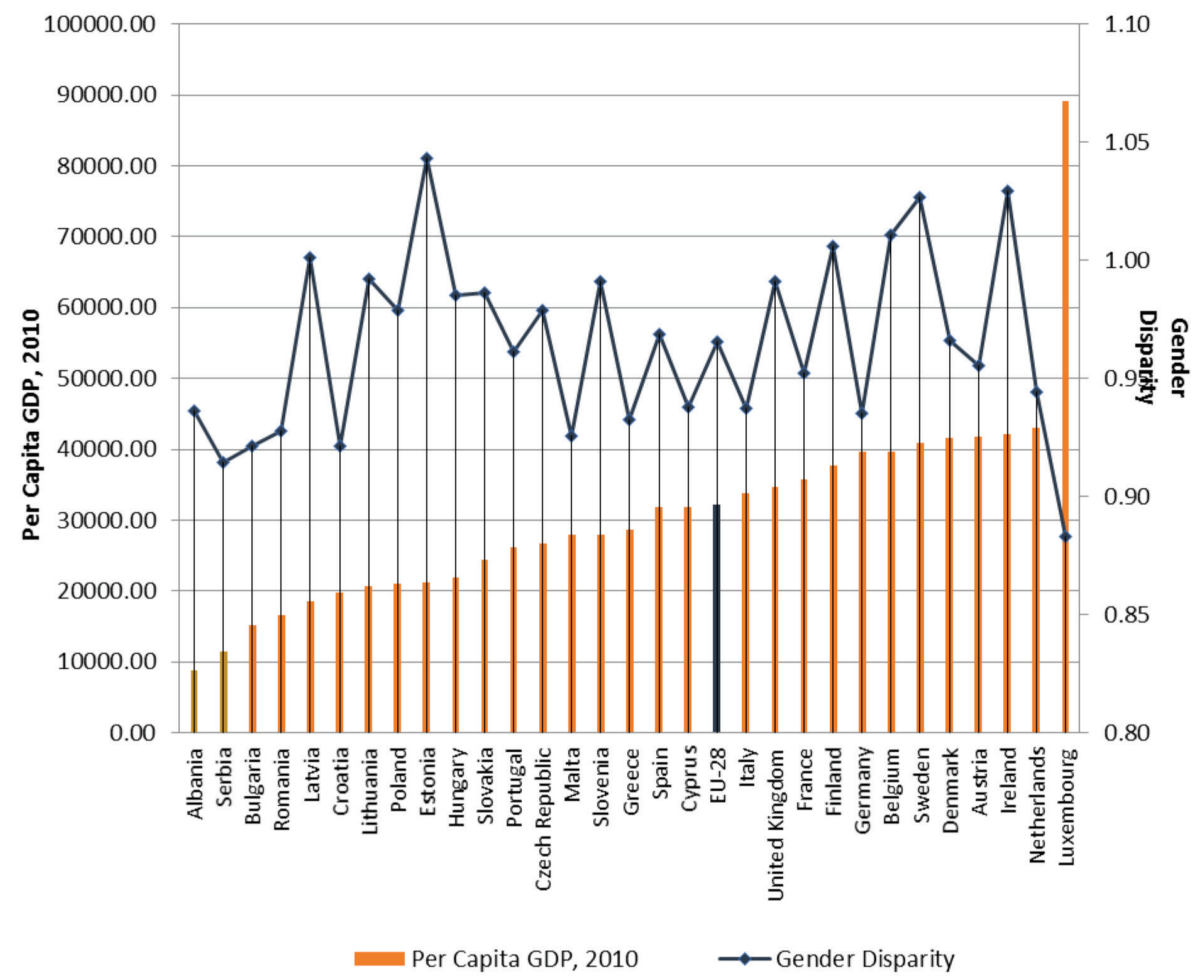

Source: Author's calculations based on Barro and Lee's (2010) data set.

Whereas Estonia, Ireland, Belgium and Finland represent the countries that have a gender disparity greater than one (1.04, 1.03, 1.01 and 1.01, respectively), meaning that the females are more educated than males in terms of average years of schooling. Even in these cases, it is difficult to conclude that there is a direct relation between economic growth and gender disparity in education since these four countries have different per capita GDP.

On the other hand, although Serbia does better in the average years of schooling, Albania fairs better in terms of gender disparity. Albania has a gender disparity in education of about 0.94 in 2010, whereas Serbia has gender disparity in education of about 0.91 . 


\section{ESTIMATED CONVERGENCE PERIOD OF ALBANIAAND SERBIA WITH EUROPEAN COUNTRIES}

As indicated above, there is a gap between Western Balkan Countries such as Albania and Serbia and European Countries in terms of years of schooling. The aim of this section is to look at the possibility of convergence and estimate the time needed to close this gap. The exponential trend method was used to calculate the annual growth rate. Albania shows a higher growth rate, of about 2.8\%, followed by Serbia and EU-28 with a growth rate of 1.7 and 1.4, respectively. These growth rates are found to be relatively high in the countries having a lower average years of schooling. This is consistent also the diminishing returns concept. Backward economies are at an advantage compared to rich countries because of diminishing returns to the accumulation of capital per head (Soukiazis, 2000). Gerschenkron (1962) was the first to present the idea that the poor countries imitate and rich countries innovate, naming this phenomena as " the advantages of relative backwardness". Elmslie and Milberg in 1996, further develop this phenomena by arguing that diminishing returns characteristics might also come from the services and education sectors. In this case too, the educational attainment is conform to the diminishing returns concept. Siljak and Nagy (2018) in their empirical study done for time interval 2004-2013 have found that the Western Balkan countries converge towards the EU-28 Member States in economic aspects.

Comparing growth rates, as expected, the females' growth rates are higher that males' growth rates. This is because females have fewer number of schooling years.

Table 1.: Annual Growth Rate in Years of Schooling, 1950-2010 (in percentage)

\begin{tabular}{|c|c|c|c|}
\hline Countries & Total & Male & Female \\
\hline EU-28 & 1.4 & 1.3 & 1.5 \\
\hline Albania & 2.8 & 2.5 & 3.1 \\
\hline Serbia & 1.7 & 1.3 & 2.1 \\
\hline
\end{tabular}

Source: Author's calculations based on Barro and Lee's (2010) data set.

As noted in Table 1. and in Figure 5., countries with lower per capital GDP such as Albania, having a very low human capital in 1950s, (about 2.32), have made remarkable progress increasing years of schooling. Obviously, countries starting with high years of schooling find it more challenging to significantly further increase years of schooling, thus experiencing lower growth rates. Convergence in human capital can thus be expected because the time spent for schooling has an upper limit - people cannot study forever (Hyun H. Son, 2010). 
Table 2.: Convergence Year to EU-28 based on Annual Growth Rate of Years of Schooling, Base Year 2017

\begin{tabular}{|c|c|c|}
\hline Countries & Convergence Year & Years to catch up EU-28 \\
\hline Albania & 2019 & +2 years \\
\hline Serbia & 2021 & +4 years \\
\hline
\end{tabular}

Source: Author's calculations based on Barro and Lee's (2010) data set, the UIS database and UN population database.

To estimate the time needed for the convergence, it is assumed that the countries will continue to have the same growth rate they have experienced in the last 60 years, as calculated in Table 1 . However, during the years, as countries are experiencing increases in the years of schooling, the calculated real growth rates can be even lower. Therefore, the results found in Table 2. are better to be considered as the lower limit time needed to convergence of Albania and Serbia to EU-28. Table 2 show that Albania will need at least 2 more years to catch up the EU-28 level, whereas Serbia needs at least 4 years, seen its' low growth rate. The result seems to be surprising because Serbia is having higher average of years of schooling, but Albania is showing a rapider growth rate than Serbia.

\section{CONCLUSIONS}

Human capital is found to be one of the main inputs such as capital and land of Economic growth. Human capital, defined as education level (human capital refers to more than education level), which can include quantitative and/or qualitative indicators, essentially represents the production capacities of the people. Given the various proxies proposed to measure the human capital, this study uses the average years of schooling. This study used the data set (1950-2010) retrieved from Barro and Lee (2010) and for the years 2010-2015 from the UIS database and UN population database.

The research compared Albania and Serbia with the European Countries regarding human capital and the performance of these two countries in approaching their human capital level to the average of EU countries. Albania, having the lowest average years of schooling and the lowest GDP level, coupled with a lower gender disparity in education, is expected to have a higher growth rate of education. Assuming that the growth rate of education will continue to remain the same, the results show that Albania may catch up the average of EU countries education level by 2019. As for Serbia, the convergence may occur no earlier than 2021. Even though Serbia has a better performance in education level and GDP, its growth rate of education, approximately 1.7 percent, is lower than that of Albania. At the same time, the gender disparity in Serbia is found to be much higher than Albania but the females impact in this country's convergence to the average of EU countries will be much more significant. 


\section{REFERENCES}

Azariadis, Costas, and Allan Drazen. "Threshold externalities in economic development." The Quarterly Journal of Economics 105, no. 2 (1990): 501-526

Baldacci, Emanuele, Benedict Clements, Sanjeev Gupta, and Qiang Cui. "Social spending, human capital, and growth in developing countries." World development 36, no. 8 (2008): 1317-1341

Barro, Robert J. "Economic growth in a cross section of countries." The quarterly journal of economics 106, no. 2 (1991): 4.07-4.3

Barro, Robert J. "Government spending in a simple model of endogeneous growth." Journal of political economy 98, no. 5, Part 2 (1990): S103-S125

Barro, Robert J., and Jong Wha Lee. "International measures of schooling years and schooling quality." The American Economic Review 86, no. 2 (1996): 218-223

Barro, Robert J., and Jong-Wha Lee. "A New Data Set of Educational Attainment in the World, 19502010. NBER Working Paper No. 15902." National Bureau of Economic Research (2010).

Barro, Robert J., and Jong Wha Lee. "International data on educational attainment: updates and implications." oxford Economic papers 53, no. 3 (2001): 541-563

Benhabib, Jess, and Mark M. Spiegel. "The role of human capital in economic development evidence from aggregate cross-country data." Journal of Monetary economics 34, no. 2 (1994): 14,3-173

Bils, Mark, and Peter J. Klenow. "Does schooling cause growth?." American economic review 90, no. 5 (2000): 1160-1183

Cohen, Daniel, and Marcelo Soto. "Growth and human capital: good data, good results." Journal of economic growth 12, no. 1 (2007): 51-76

Dellink, Rob, Jean Chateau, Elisa Lanzi, and Bertrand Magné. "Long-term economic growth projections in the Shared Socioeconomic Pathways." Global Environmental Change 42 (2017): 200-214

Durlauf, Steven N., and Paul A. Johnson. "Multiple regimes and cross-country growth behaviour." Journal of applied econometrics 10, no. 4 (1995): 365-384

Elmslie, Bruce, and William Milberg. "The productivity convergence debate: A theoretical and methodological reconsideration." Cambridge Journal of Economics 20, no. 2 (1996): 153-182

Gerschenkron, Alexander. Economic backwardness in historical perspective: a book of essays. No.

33o.947 G381. Cambridge, MA: Belknap Press of Harvard University Press, 1962.

Hanushek, Eric A., and Dennis D. Kimko. "Schooling, labor-force quality, and the growth of nations." American economic review 90, no. 5 (2000): 1184-1208

Hanushek, Eric A., and Dongwook Kim. Schooling, labor force quality, and economic growth. No. w5399. National bureau of economic research, 1995.

Hanushek, Eric A., and Ludger Wößmann. The role of school improvement in economic development. No. w12832. National Bureau of Economic Research, 2007.

Human Development Report 2015, Work For Human Development. 2015, report.hdr.undp.org.

Islam, Nazrul. "Growth empirics: a panel data approach." The Quarterly Journal of Economics 110, no. 4 (1995): $1127^{-1170}$ 
Klasen, Stephan. "Low schooling for girls, slower growth for all? Cross-country evidence on the effect of gender inequality in education on economic development." The World Bank Economic Review 16, no. 3 (2002): $345^{-3} 7^{3}$

Krueger, Alan B., and Mikael Lindahl. "Education for growth: Why and for whom?." Journal of economic literature 39, no. 4, (2001): 1101-1136

Levine, Ross, and David Renelt. "A sensitivity analysis of cross-country growth regressions." The American economic review (1992): 942-963

Lucas Jr, Robert E. "Making a miracle." Econometrica: Journal of the Econometric Society (1993): 251272

Madsen, Jakob B., and Fabrice Murtin. "British economic growth since 1270: the role of education." Journal of Economic Growth 22, no. 3 (2017): 229-272

Mankiw, N. Gregory, David Romer, and David N. Weil. "A contribution to the empirics of economic growth." The quarterly journal of economics 107, no. 2 (1992): 4.07-4.37

Pritchett, Lant. "Where has all the education gone?." The world bank economic review 15, no. 3 (2001): $367^{-391}$

Romer, Paul M. "Endogenous technological change." Journal of political Economy 98, no. 5, Part 2 (1990): $\mathrm{S}_{71}-\mathrm{S}_{102}$

Siljak, Dzenita, and Sándor Gyula Nagy. "The effects of the crisis on the convergence process of the Western Balkan countries towards the European Union." Society and Economy4, O, no. 1 (2018): 105

Soukiazis, Elias. "What have we learnt about convergence in Europe? Some theoretical and empirical considerations." Unpublished manuscript, 2000.

Temple, Jonathan. "The new growth evidence." Journal of economic Literature 37, no. 1 (1999): 112-156 